\title{
Instrument for the Visualization and Evaluation of the Intellectual Property Assets in the Knowledge Based Economy
}

\author{
Mihail Aurel ȚîȚU \\ „Lucian Blaga” University of Sibiu, Sibiu, Romania \\ mihail.titu@ulbsibiu.ro \\ Constantin OPREAN \\ „Lucian Blaga” University of Sibiu, Sibiu, Romania \\ constantin.oprean@ulbsibiu.ro \\ Andreea Simina RĂULEA \\ „Lucian Blaga” University of Sibiu, Sibiu, Romania \\ andreea.raulea@ulbsibiu.ro \\ Ștefan ȚîȚU \\ „Iuliu Hațieganu” University of Medicine and Pharmacy, Cluj Napoca, Romania \\ stefan.titu@ymail.com
}

\begin{abstract}
The intellectual property is a concept of whose content and materialization find themselves more and more in the attention of the researchers and practitioners. The increased number of the works that approach such an issue is the argument that supports the previous affirmation. The intellectual property assets attract the interest of all the organizations from the local to the global level. The important pillars of the European Strategy 2020 formulated by the European Commission are based on the capitalization of the innovation knowledge and of the intellectual property. The increased interest towards innovation and intangible assets is given to the awareness of their economic potential. This is the reason why the evaluation and the valuation of the intellectual property capitalization propose an evaluation methodology unanimously accepted. The aim of this article is to present a visualization and evaluation instrument for the intellectual property assets, realized in a framework of a European research project with 15 partners from countries that are situated in the South Eastern Europe.
\end{abstract}

Keywords: evaluation for the intellectual property assets, knowledge based economy, intellectual property. 


\section{INTRODUCTION}

The economy, the organization and the knowledge based management are common used concepts when we talk about the new economic tendencies. This fact is given mainly because of the knowledge revolution from the XXI century, which brought to the attention the "knowledge", seen as a main element in the assurance of functionality and the efficiency of the organizations.

In the new conditions imposed by the accelerated changes and by the more and more complex changes in the business environment, the economic restructuring comes as a necessity in the global level.

The study of the historical evolution regarding the different types of societies emphasizes the fact that at the level of high societies reach and maintain those societies that invest in their innovation activities (Slătineanu, 2015).

The knowledge based economy is a new type of economy that works out in the developed countries for the last decades. This is totally different compared to the type of the industrial economy or its postindustrial version.

According to the OCDE, the knowledge based economy is "the economy directly based on the production, distribution and usage of the knowledge and of the information". This definition was rapidly taken in numerous developed countries and used for prefigure the economic future. An apogee of it was represented by the summit of the European Union from Lisbon, where was established as fundamental purpose for the countries that form this organization, the constitution of the knowledge based economy.

The main features of the knowledge based economy are presented in figure no 1 . These give a broad view, accurate enough for seizing the specificity of the knowledge based economy and the essential differences in what concerns the economy from the current times.

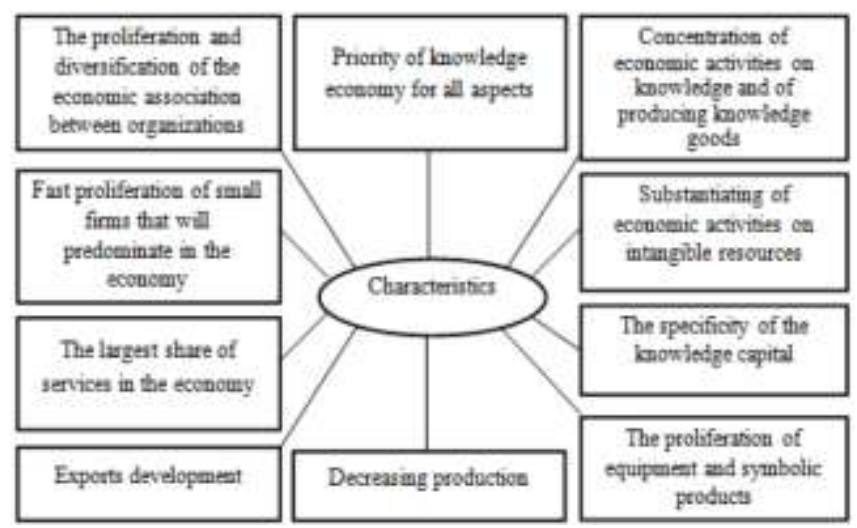

Figure 1: The main features of the knowledge based economy. 
The passage to the knowledge based economy, to the building and to the functioning of the knowledge based economy can't be realized without a knowledge based management (Oprean, 2011). To the level of the organizations, the knowledge is found to the level of the human capital, in the requests and the preferences of the clients, more precisely the clients capital, in the products, the processes, the capabilities and the systems of it, all these that form the structural capital.

As a result, the value of the knowledge assets can significant overcome the value of the assets (Oprean, 2011).

In the framework of every organization there takes place three major processes linked to the knowledge (Oprean, 2011):

- The acquiring or achieving of knowledge that is realized through the processes of learning by the organization's employees;

- The creation of knowledge in the form of inventions, innovations, etc.;

- The use of knowledge, through all the actions and the decisions that are being shaped later in products, services, new information, that are traded in profitable circumstances.

The conditioning in the terms of acquiring economic performances represents a branch of a revolution that has a foreground the knowledge. Moreover, the knowledge will become a priceless resource in the provision with management examples and valuation of the economic potential for the intangible assets of the innovators and researchers (Manus, 2012).

\section{THEORETICAL CONSIDERATIONS THAT ARE APPLIED IN THE INTELLECTUAL PROPERTY MANAGEMENT}

The intellectual property, especially the patents seem to bring a significant contribution to the value of the organizations market. The need of an improved evaluation is strongly linked to the expansion of the use of the intellectual property. The evaluation and the exploit evolve together over the time. The need for an adequate evaluation of the intellectual property is motivated even more by the expansion of its use in the application that expand out of the organizations.

The need of financial evaluations of the intellectual property becomes relevant especially when these are used as instruments of financing by the organizations and as investment assets assured by the financial institutions. The analysts and the financial investors consider more often the intellectual property as a key element in the value of the organization and a sign of its technological capacities.

In the case of the organizations, especially in the small and medium enterprises that do not own internal sources of financing and a necessary portfolio of success for attracting the external investors, the patents are considered a manner of attracting and assuring from a financial point of view. Owning a strong portfolio of intellectual properties can signal to 
the investors that the company has a technological advantage against its competitors- one that can be protected by the patent law (Weltz, Fichtinger \& Kerschbaum, 2013).

The basis methods for evaluation are very much alike, fact that reduces the complexity and helps in the finding the key- issues of the management. Any evaluation exercise can be seen as a pyramid, where each level supports the analysis generated by the superior level.

To the highest level of the pyramid is approached the important problem of the way that the evaluation analysis solves a business problem or generates a recommendation to a specific business issue (Weltz, Fichtinger \& Kerschbaum, 2013).

The purpose of the evaluation defines the regulation and legal statuses, the judiciary court of resolution, the accepted methodologies and the basic rules that have been developed in that domain.

The companies can value their intangible assets by selling, dismissing or through a variation or combination of these. This thing has stimulated the selling a dismissing transactions between the medium and small companies and between the non- practicing entities, using various business models for the capitalization of the intellectual property assets.

The biggest obstacle in stimulating the interest and the activities in the financial sector by intangible assets is the uncertainty that surrounds the evaluation of the intangible assets.

The business evaluation is seen more like an art than as a science in many places. For example, the evaluation of a patents or trademarks portfolio of a brand is an even bigger challenge because of its inherent unique of the intangible assets and of the preoccupations linked to their possibility of transfer.

The companies are exploring more and more the intellectual property as a way of accessing the external resources of financing. The intellectual properties can play the role of facilitating the attraction of investments with risk capital, being also used as goods on the traditional financial markets, banking debts and the markets of securities (Weltz, Fichtinger \& Kerschbaum, 2013). For example the banks begin to accept patents as a guarantee for the bank loans and to develop securities guaranteed by the intellectual property that the owners of the patents can use in obtaining the financing.

\section{EVLIA METHOD FOR THE IDENTIFICATION AND DESCRIPTION OF THE COMPETITIVE RELEVANT ASSETS}

The intellectual property represents an important resource in the processes of innovation and it is a part of the intangible assets portfolio of an organization. Even so, there aren't enough evaluated and treated as real assets in the bookkeeping by the experts of the financial market, like the majority of the other assets. There is still missing a global approach that should be standard, of the valuation at the European level and also to the 
global level. So, nowadays the experts in investments apply traditional methods combined with additional information of the market, according to the specific circumstances.

The leading point of the global study regarding the emergent standards for the capitalization of the intangible assets is the current national development of the valuation instruments of the rights for the intellectual property in Europe towards other regions of the world. (Fichtinger, Mösenbacher \& Weltzl, 2013).

So, these developments must be analyzed according to the supranational programs and of negotiation at the level of The Cooperation and Economic Development Organization, The Global Organization for the Intellectual Property and to the level of The Global Organization of Trade.

In some European countries there already are some projects and pilot experiences regarding the valuation of the intangible assets that the European project EVLIA used as an advantage (Fichtinger, Mösenbacher \& Weltzl, 2013). In what concerns the acceptance of the capitalization of the patents and the use of them on the market it is very important to understand how the banks and other financial institutions handle the assets as intellectual property in the framework of their internal procedures and how they use this category in their businesses.

Any method of evaluation of the intangible assets at the European level will encounter difficulties because of the national bookkeeping standards differences regarding the treatment of the patents (Fichtinger, Mösenbacher \& Weltzl, 2013). The main purpose of every bookkeeping standard is to give a complete vision, accurate and equitable over the financial situation of an organization. Even so, the bookkeeping standards failed to adapt entirely to this continuous process where de business become more and more dependent of the value of their intangible assets.

The EVLIA project - Making full value of good ideas by leveraging intellectual assets for financing SMEs in SEE, implemented and tested a standard methodology by the implication of the financial organizations. According to this methodology, any organization that wishes to evaluate and value their intangible assets and to complete a preliminary questionnaire for the analysis of the intangible assets must realize a business plan with a special section dedicated to the intangible assets and must evaluate the brand and the patents.

This methodology is the result of some researches and analyses of all the existent practices, and has been identified signs of great importance in the valuation and evaluation of the intangible assets. So, has been identified four groups of intangible assets which are relevant from the competitive point of view, more exactly: human resources, intellectual property, organizational capital and relational capital. Each group of intangible assets can be defined as we can see in the table 1 . 
Table 1: Intangible assets structure.

\begin{tabular}{|c|c|c|c|}
\hline & & Human & $\begin{array}{l}\text { Entrepreneurial experience } \\
\text { Staff competences }\end{array}$ \\
\hline & & resources & Tacit knowledge \\
\hline & & & Staff motivation and loyalty \\
\hline & & & Codified knowledge \\
\hline & Intellectual & Intellectual & $\begin{array}{l}\text { Business information and } \\
\text { proprietary technologies. Trade } \\
\text { and business secret and their } \\
\text { management }\end{array}$ \\
\hline & & property & $\begin{array}{l}\text { Inventions: awareness and } \\
\text { protection }\end{array}$ \\
\hline & & & Trademarks and brands \\
\hline & & & Designs and models \\
\hline & & & Copyrights and related rights \\
\hline Intangible & & & $\begin{array}{l}\text { Methods/procedures for } \\
\text { production/supply of services }\end{array}$ \\
\hline & & Organizational & Certifications \\
\hline & & capital & $\begin{array}{l}\text { Project management tools and } \\
\text { systems }\end{array}$ \\
\hline & Capital & & Administrative System \\
\hline & Structural & & Customer attraction \\
\hline & & Relational & Customers portfolio management \\
\hline & & & Suppliers management \\
\hline & & & Cooperation and networks \\
\hline
\end{tabular}

Each intangible asset is analyzed after it model of creation, function, programming and transferability (table 2).

Table 2: Types of analysis indicators of the intangible asset.

\begin{tabular}{|l|l|l|l|}
\hline \multicolumn{1}{|c|}{ Creation } & \multicolumn{1}{|c|}{ Functioning } & \multicolumn{1}{c|}{ Programming } & \multicolumn{1}{c|}{ Transferability } \\
\hline $\begin{array}{l}\text { - the modality } \\
\text { through which } \\
\text { the asset is } \\
\text { obtained. }\end{array}$ & $\begin{array}{l}\text { - the modality of } \\
\text { using the asset } \\
\text { and how it } \\
\text { contributes to the } \\
\text { business model. }\end{array}$ & $\begin{array}{l}\text { - the modality } \\
\text { through which } \\
\text { the regeneration } \\
\text { of the assets is } \\
\text { managed. }\end{array}$ & $\begin{array}{l}\text { - the relevance of } \\
\text { the asset for the } \\
\text { third parties and the } \\
\text { way they can be } \\
\text { charged for the } \\
\text { using of the asset. }\end{array}$ \\
\hline
\end{tabular}

So, depending on the availability and the relevance of those indicators, can be found four situations as we may see in figure no 2 . There must be mentioned that each organization 
must adapt to this list at the dimensions the capacity, the activity field and the market where it operates. We can sustain that there is not a completed, standard list that would function for all the organizations.

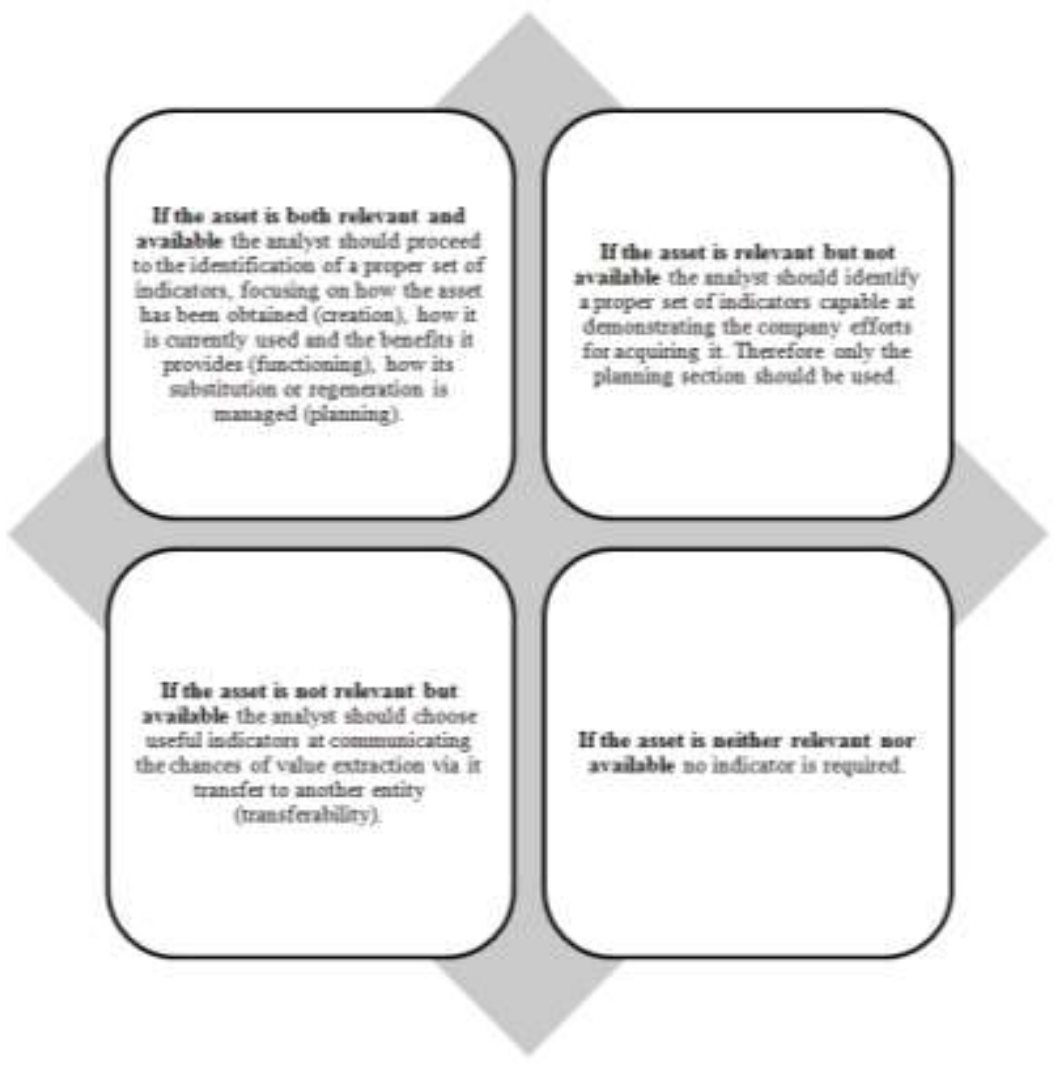

Figure 2: The relevance and availability of the intangible assets.

\section{FINAL APPRECIATIONS REGARDING THE APPLIANCE AND IMPLEMENTATION OF THE EVLIA INSTRUMENT IN THE KNOWLEDGE BASED ECONOMY}

The importance of the valuation for the intellectual property assets is indisputable, especially when we talk about an economy found in a continuous change, when the information gives power and the innovation is a must.

Taking into consideration the economic instability of the markets where the nowadays organizations are activating, the protection and valuation of the intangible assets make the difference between failure and success. So, the organizations must manage the most 
accurate possible these assets for identification of the additional modalities of capitalization.

The applicability of the EVLIA instrument will be proven in time but for the moment the first steps were made and the SMEs that responded to the preliminary questionnaire of analysis, have provided the business plans and evaluated their brand and patents, has been already put in touch with the financial institutions for being given solution in order to develop solutions for businesses based on their intellectual property assets they own.

Of course this demarche is at the beginning of its road but it is a good sign the fact that the first step has been realized, that at the European level has been proposed a draft of law that sustains the demarche we are talking about and the fact that the capitalization of the intangible assets is not just a simple idea anymore.

In the new economy the intangible assets become the new nucleus of the competences. That is the reason for what we must become aware that we live in a world that focuses on the economic value of the intangible assets. We deal with a period of time where the ideas value billions, while the products cost less and less. In this sense, the EVLIA method represents the foundation stone in a process that no longer ahead will become the equivalent of the way the tangible assets are seen now.

\section{REFERENCES}

Fichtinger, M., Mösenbacher, S., Weltzl, A. G. (2013). Methodology Paper Documentatie Proiect european de cercetare EVLIA. Ecnomica Institute of Economic Research, Vienna.

Manus, J. P. (2012). Intellectual Property: From Creation to Commercialisation - A Practical Guide for Innovators \& Researchers (ed. First). Cork, Ireland: OAK TREE PRESS.

Oprean, C., Țîțu, M., Bucur, V. (2011). Managementul global al organizaţiei bazată pe cunoştinţe. București, Romania: AGIR.

Slătineanu, L. (2015). Proprietatea industrială. Iași, Romania: PERFORMANTICA.

Weltz, A. G., Fichtinger, M., \& Kerschbaum, F. (2013). Analiza de Status Quo pentru valorificarea proprietăţii intelectuale în zona Europei de Sud Est şi în context Global. Viena: Institutul "Economica" de Cercetare Economică. 